\title{
Seasonal incidence of the sucking pest and lady bird beetle on Bt cotton
}

\author{
Rohini Khedkar ${ }^{1}$ and G.B. Kabre*2
}

${ }^{1}$ College of Agriculture, Dhule (M.S.) India

${ }^{2}$ Department of Agricultural Entomology, Post Graduate Institute, Mahatma Phule Krishi Vidyapeeth, Rahuri, Ahmednagar (M.S.) India

\section{ARITCLE INFO}

Received : 07.11 .2019

Revised : 03.02 .2020

Accepted : 18.02 .2020

\section{KEY WORDS :}

Weather parameters, Sucking pest, $\mathrm{Bt}$ cotton

*Corresponding author:

Email : kabregb@gmail.com

\begin{abstract}
Seasonal incidence of sucking pests in Kharif 2016 at College of Agriculture, Dhule revealed that, the leafhopper incidence reached its peak activity during the second week of October (6.64 leafhoppers/3 leaves/plant), whereas, the peak incidence of aphids was noticed in the third week of October ( 8.82 aphids/3 leaves/plant). The peak incidence of the whiteflies was recorded during the fourth week of October $(8.02$ whiteflies/3 leaves/plant). The peak incidence of the thrips was recorded during the third week of October (6.76 thrips/3 leaves/plant). The activity of predator lady bird beetle was at its peak during first week of October (2.94 lady bird beetles/plant), which is directly related with the activity of the sucking pest in field. The correlation between incidence of leaf hoppers $(r=0.205)$, aphids $(r=0.174)$, whiteflies $(r=0.206)$, thrips $(r=$ $0.167)$, was positively non-significant with maximum temperature $\left(\mathrm{T}_{\max }\right)$. The minimum temperature $\left(\mathrm{T}_{\text {min }}\right)$ showed negative significant correlation with whiteflies $\left(\mathrm{r}=-0.640^{* *}\right)$, thrips $(\mathrm{r}=-0.464 *)$ and negative non-significant correlation with leafhoppers $(\mathrm{r}=-0.411)$ and aphids $(\mathrm{r}=-0.3111)$. The morning relative humidity $(\mathrm{MRH})$ showed negative significant correlation with occurrence of whiteflies $(r=-0.440 *)$ and negative non significant correlation with occurrence of the leafhoppers $(r=-0.123)$, aphids $(r=-$ $0.101)$ and thrips $(r=-0.184)$. Similarly, the evening humidity $($ ERH) showed negative non significant correlation with the pests such as leafhoppers $(\mathrm{r}=-0.038)$, aphids $(\mathrm{r}=$ $0.021)$, whiteflies $(r=-0.166)$ and thrips $(r=-0.085)$ during Kharif 2016 season. The rainfall had negatively non significant effect at 5 per cent level of significance with leafhoppers, aphids, whitefly and thrips.
\end{abstract}

How to view point the article : Khedkar, Rohini and Kabre, G.B. (2020). Seasonal incidence of the sucking pest and lady bird beetle on Bt cotton. Internat. J. Plant Protec., 13(1) : 9-13, DOI : 10.15740/HAS/IJPP/13.1/9-13, Copyright@ 2020: Hind Agri-Horticultural Society. 